\title{
EGCG attenuates atherosclerosis through the Jagged-1/Notch pathway
}

\author{
JIANGUO YIN $^{1}$, FANG HUANG ${ }^{2}$, YUHONG YI ${ }^{1}$, LIANG YIN $^{1}$ and DAOQUAN PENG ${ }^{1}$ \\ ${ }^{1}$ Department of Cardiology, The Second Xiangya Hospital of Central South University, Changsha, Hunan 410011; \\ ${ }^{2}$ Department of Cardiology, The First Hospital of Changsha, Changsha, Hunan 410011, P.R. China
}

Received June 4, 2015; Accepted November 19, 2015

DOI: $10.3892 / \mathrm{ijmm} .2015 .2422$

\begin{abstract}
Atherosclerosis is the most common cause of cardiovascular diseases worldwide. Oxidized low-density lipoprotein (ox-LDL) is a particularly important risk factor in the pathogenesis of atherosclerosis. Accumulating evidence has indicated that epigallocatechin-3-gallate (EGCG; a catechin found in the popular beverage, greent tea) protects against ox-LDL-induced atherosclerosis. However, the underlying mechanisms remain unclear. In the present study, ox-LDL (100 mg/l) induced damage to, and the apoptosis of human umbilical vein endothelial cells (HUVECs) by reducing endothelial nitric oxide synthase (eNOS) expression and promoting inducible nitric oxide synthase (iNOS) expression; these effects were abrogated by the addition of $50 \mu \mathrm{M}$ EGCG. Furthermore, ox-LDL rapidly activated the membrane translocation of $\mathrm{p} 22^{\text {phox }}$, and altered the protein expression of Jagged-1 and Notch pathway-related proteins [Math1, hairy and enhancer of split (HES)1 and HES5]; these effects were also prevented by pre-treatment with $50 \mu \mathrm{M}$ EGCG. In addition, Jagged-1 played a significant role in the EGCG-mediated protection against ox-LDL-induced apoptosis and ox-LDL-diminished cell adhesion in the HUVECs. Finally, EGCG inhibited highfat diet (HFD)-induced atherosclerosis in apolipoprotein $\mathrm{E}$ (ApoE) knockout (ApoE-KO) mice through the Jagged-1/ Notch pathway. Taken together, these findings demonstrate that $50 \mu \mathrm{M}$ EGCG protects against ox-LDL-induced endothelial dysfunction through the Jagged-1/Notch signaling pathway. Moreover, our data provide insight into the possible molecular mechanisms through which EGCG attenuates ox-LDL-induced vascular endothelial dysfunction.
\end{abstract}

Correspondence to: Professor Daoquan Peng, Department of Cardiology, The Second Xiangya Hospital of Central South University, 139 Middle Renmin Road, Changsha, Hunan 410011, P.R. China E-mail: pengdq@hotmail.com

Key words: epigallocatechin-3-gallate, oxidized low-density lipoprotein, human umbilical vein endothelial cells, atherosclerosis, Jagged-1, Notch, pathway

\section{Introduction}

Atherosclerosis is a multifactor cardiovascular disease, which is associated with physiological and behavioral risk factors, such as age, gender, hypertension, hypercholesterolemia, obesity, diabetes, smoking and a sedentary lifestyle (1). Studies have indicated that chronic inflammatory responses and oxidative stress conditions in vascular tissue are associated with the pathogenesis of atherosclerosis (2). Oxidized low-density lipoprotein (ox-LDL) is a particularly important risk factor for the pathogenesis of atherosclerosis. It is well known that ox-LDL promotes the occurrence and development of atherosclerosis through various mechanisms, including the induction of endothelial cell damage. In addition, ox-LDL causes endothelial cell activation, dysfunction and death, as well as impaired vasorelaxation, which contribute causally to the development and progression of atherosclerosis (3-5). Accumulating has indicated that ox-LDL-mediated biological processes may be related to the increased activity of NADPH oxidase (6-8). NADPH oxidase, a multisubunit enzymatic complex comprised of two membrane-bound subunits, gp91 and $\mathrm{p} 22^{\text {phox }}$, is the major source of intracellular reactive oxygen species (ROS) in vascular cells. Moreover, cytoplasmic subunits, such as $\mathrm{p} 47^{\text {phox }}$ and $\mathrm{p} 67^{\text {phox }}$ are critical components of endothelial NADPH oxidase. For example, it has been demonstrated that the activation of Rac-1 and $\mathrm{p} 47^{\text {phox }}$ is involved in the generation of superoxide, a molecule that stimulates inflammatory gene expression through a redox-sensitive signaling pathway in vascular endothelial cells (9).

Green tea is a one of the most ancient and popular beverages consumed worldwide, and it has been suggested to prevent the development of a variety of diseases, including diabetes, hypertension, cancer and cardiovascular diseases (10). The effects of green tea are attributed to its abundant and biologically active catechin, epigallocatechin-3-gallate (EGCG), which has antioxidant (11), anti-inflammatory (12), anti-tumorigenic (13) and anti-angiogenic (14) effects. Accumulating evidence has indicated that EGCG plays an important role in the protection against the initiation and/or development of atherosclerosis (15). Previous studies have demonstrated that EGCG possesses potent antioxidant properties, which attenuate oxidative injury induced by ox-LDL in endothelial cells (16-19). In a recent study, Cai et al demonstrated that green tea EGCG attenuated Porphyromonas gingivalis-induced atherosclerosis (15). Based 
on the findings of previous studies, we hypothesized that EGCG may protect endothelial cells against ox-LDL-induced damage by suppressing the ox-LDL-induced activity of NADPH oxidase.

The Notch pathway is an evolutionary highly conserved signaling system. Thus far, 4 Notch receptors (Notch1-4) and 5 ligands [Delta-like (D11)-1, -3, -4 and Jagged (JAG)-1 and -2] have been identified in vertebrates. The Notch signaling pathway shows functional significance in neural development $(20,21)$, multiple cellular processes, embryonic development and self-renewing adult tissues $(22,23)$. Recently, Notch signaling was proven to be critical for arterial specification, sprouting angiogenesis and vessel maturation (24-27). However, little is known about the function of the Jagged-1/Notch pathway in the protective effects exerted by EGCG against ox-LDL-induced endothelial cell damage.

In this study, ox-LDL-exposed endothelial cells were treated with various concentrations of EGCG, to examine the hypothesis that $50 \mu \mathrm{M}$ EGCG may hamper ox-LDL-induced endothelial cell damage by modulating the Jagged-1/Notch pathway.

\section{Materials and methods}

Cell culture. Human umbilical vein endothelial cells (HUVECs) were purchased from the American Type Culture Collection (ATCC; Rockville, MD, USA) and cultured in RPMI-1640 (Invitrogen, Carlsbad, CA, USA) supplemented with $10 \%$ fetal bovine serum (FBS) and $100 \mu \mathrm{g} / \mathrm{ml}$ penicillin/streptomycin (both from Invitrogen).

Isolation of endothelial progenitor cells (EPCs). The isolation and culture of EPCs was performed as previously described (28). Mononuclear cells were isolated from the bone marrow of apolipoprotein E (ApoE) knockout (ApoE-KO or $\mathrm{ApoE}^{-/}$) mice by flushing the femurs and tibias of the mice. Briefly, the mice $(n=5)$ were anesthetized by an intraperitoneal injection of $10 \%$ chloral hydrate $(0.3 \mathrm{ml} / 100 \mathrm{~g})$ and then sacrificed by cervical dislocation. After disinfecting the area with alcohol and performing muscle incision, the whirlbone of the thigh was clipped and a needle was inserted into the bone tube to flush out the bone marrow using sterilized PBS. The bone marrow was then cultured in selective medium (EGM-2; CC-3162; Lonza, Walkersville, MD, USA) for 14 days. The Institutional Animal Care and Use Committee of Central South University approved all the animal protocols. Following isolation, the cells were plated immediately onto 6-well plates pre-coated with fibronectin (Sigma-Aldrich, St. Louis, MO USA) at a density of $5 \times 10^{6}$ cells/well and cultured in RPMI-1640 (Gibco Life Technologies, Grand Island, NY, USA) with 10\% FBS (Gibco Life Technologies). The cells were incubated at $37^{\circ} \mathrm{C}$ in $5 \% \mathrm{CO}_{2}$. The culture medium was changed every 3 days. After 4 days in culture, the non-adherent cells were washed away with $0.01 \mathrm{~mol} / \mathrm{l}$ phosphate-buffered saline (PBS; $\mathrm{pH}$ 7.4) and fresh medium was then added. The EPCs after 7 days of culture were used in the experiments. To confim the identity of the EPCs prior to use, western blot analysis was performed to detect EPC-specific surface markers [CD34, CD133 and vascular endothelial growth factor receptor (VEGFR)-2] (data not shown).

Preparation of ox- $L D L$. Human ox-LDL was obtained from Shanghai Luwen Biotech Inc. (LW-6002; Shanghai, China).
LW Human LDL had been purified to homogeneity via ultracentrifugation (1.019-1.063 g/cc) and had been oxidized using $5 \mu \mathrm{M} \mathrm{Cu}_{2} \mathrm{SO}_{4}$ (oxidant) ihn PBS at $37^{\circ} \mathrm{C}$ for $20 \mathrm{~h}$. The reaction was terminated by the addition of EDTA- $\mathrm{Na}_{2}$. The concentration of ox-LDL used in the present study was $100 \mathrm{mg} / \mathrm{l}$.

Mice and treatments. Six-week-old male ApoE-KO mice were obtained from Xiangya Hospital of Central South University, Changsha, China. The mice were randomly divided into 3 groups $(n=5)$ and administered for 7 weeks (via their drinking water) with the treatments: 2 groups were administered distilled water, and the other group was administered $0.8 \mathrm{~g} / 1$ EGCG (Sigma-Aldrich). As previously described (15), the mice in the EGCG group and those in the distilled water groups were fed a high-fat diet (HFD). All the mice were monitored until sacrifce (by cervical dislocation) at the age of 15 weeks and the tissue samples of the ApoE $\mathrm{E}^{-/-}$mice were then collected. All the animal protocols were approved by the Institutional Animal Care and Use Committee of Central South University.

Manipulation of Jagged-1 expression levels. pCDNA3.1 vectors containing Jagged-1 (pCDNA3.1-Jagged-1) and pRNAT-U6.1/Neo vectors containing Jagged-1 shRNA (pRNAT-U6.1/Neo-Jagged-1-sh) were constructed and transfected into the HUVECs. To confirm the effects of the vectors on the expression of Jagged-1, western blot analysis was performed to measure the protein expression levels of Jagged-1 in the HUVECs. The transfected cells were expanded and harvested for further analysis. Untransfected cells were used as controls (Con) and cells transfected with empty carrier vectors (pCDNA3.1 or pRNAT-U6.1/Neo) served as the negative control (NC).

Isolation of $m R N A$ and reverse transcription-quantitative polymerase chain reaction $(R T-q P C R)$. Total RNA was isolated from the HUVECs or the EPCs using TRIzol reagent (Invitrogen) and then reverse transcribed into cDNA using the RevertAid ${ }^{\mathrm{TM}}$ First Stand cDNA Synthesisi kit (Thermo Fisher Scientific, Waltham, MA, USA). The relative expression levels were detected using Real-Time PCR SYBR-Green Reagents (Dongsheng, Xian, China) in accordance with the manufacturer's instructions. Target RNA levels were normalized to $\beta$-actin. The primer sequences used in this study are listed in Table I.

Cell survival assay. The 3-(4,5-dimethylthiazal-2-yl)-2,5-diphenyl-tetrazolium bromide (MTT) assay was used to estimate cell viability, as prevoiusly described (29). Briefly, the cells were plated at a density of $1 \times 10^{4}$ cells/well in 96 -well plates. After being subjected to the specific treatments, the cells were incubated with MTT solution at a final concentration of $0.5 \mathrm{mg} /$ $\mathrm{ml}$ for $4 \mathrm{~h}$ at $37^{\circ} \mathrm{C}$. After the removal of the medium, $150 \mathrm{mM}$ DMSO were added to dissolve the formazan crystals. The absorbance was read at $570 \mathrm{~nm}$ using a multi-well scanning microplate reader (Thermo Fisher Scientific). The cells in the control group were considered $100 \%$ viable.

Western blot analysis. Protein lysates were separated by $10 \%$ SDS-polyacrylamide gel electrophoresis and then electroblotted onto PVDF membranes. Primary antibodies against inducible nitric oxide synthase (iNOS), endothelial nitric oxide 
Table I. Primer sequences used for RT-qPCR.

\begin{tabular}{|c|c|c|}
\hline Gene & & Primer sequence $\left(5^{\prime} \rightarrow 3^{\prime}\right)$ \\
\hline $\mathrm{p} 22^{\text {phox }}$ & $\begin{array}{l}\text { Sense } \\
\text { Antisense }\end{array}$ & $\begin{array}{l}\text { ATTGTGGCGGGCGTGTT } \\
\text { e GCACCGAGAGCAGGAGAT }\end{array}$ \\
\hline $\mathrm{p} 47^{\text {phox }}$ & $\begin{array}{l}\text { Sense } \\
\text { Antisense }\end{array}$ & $\begin{array}{l}\text { CCTGACGAGACGGAAGACC } \\
\text { e CTTTCCTGATGACCCACCA }\end{array}$ \\
\hline p67 $7^{\text {phox }}$ & $\begin{array}{l}\text { Sense } \\
\text { Antisense }\end{array}$ & $\begin{array}{l}\text { CAGACAGAGAAATATGATTTGGC } \\
\text { e GGATCACCACTGGCTCATATAG }\end{array}$ \\
\hline HES1 & $\begin{array}{l}\text { Sense } \\
\text { Antisense }\end{array}$ & $\begin{array}{l}\text { GAAGGAAGTGGTCGAAGCTC } \\
\text { e ATGCGCGTCACTTTCCAG }\end{array}$ \\
\hline Jagged-1 & $\begin{array}{l}\text { Sense } \\
\text { Antisense }\end{array}$ & $\begin{array}{l}\text { ACCTGCCAGTGCCTGAATG } \\
\text { e AGGCAAGGTCGAGGGCC }\end{array}$ \\
\hline$\beta$-actin & $\begin{array}{l}\text { Sense } \\
\text { Antisense }\end{array}$ & $\begin{array}{l}\text { AGGGGCCGGACTCGTCATACT } \\
\text { e GGCGGCACCACCATGTACCCT }\end{array}$ \\
\hline
\end{tabular}

synthase (eNOS), NADPH (p47 $\left.7^{\text {phox }}\right)$, NADPH (p67 $\left.7^{\text {phox }}\right)$, NADPH (p22 $\left.{ }^{\text {phox }}\right)$, Jagged-1, hairy and enhancer of split (HES)1, HES5 and Math1 were used, with $\beta$-actin antibody as an internal control. Densitometric analysis was performed using LabWorks Image Acquisition and Analysis software (UVP, Inc., Upland, CA, USA).

Annexin $V$ and propidium iodide (PI) binding assay. The HUVECs were cultured in 6-well plates and exposed to ox-LDL $(50 \mu \mathrm{g} / \mathrm{ml})$ for $0,12,24$ and $48 \mathrm{~h}$. The cells were harvested and stained using the Annexin V-FITC Apoptosis Detection kit (Beyotime Biotech, Jiangsu, China) according to the manufacturer's instructions. Briefly, $5 \times 10^{5}$ cells were suspended in $500 \mu \mathrm{l} 1 \mathrm{X}$ binding buffer (10 mM HEPES pH 7.4, $140 \mathrm{mM} \mathrm{NaCl}, 2.5 \mathrm{mM} \mathrm{CaCl}_{2}$ ). The cells were then incubated with Annexin V (1:20) for 5 min followed by incubation with PI $(1 \mathrm{mg} / \mathrm{ml})$ for $15 \mathrm{~min}$. The apoptotic rate was evaluated by flow cytometry.

Adhesion assay. The HUVECs $\left(1 \times 10^{5}\right.$ cells $\left./ \mathrm{ml}\right)$ were cultured in 96 -well flat-bottom plates $(0.1 \mathrm{ml} /$ well $)$ for $1-2$ days. The cells were then pre-treated with the indicated concentrations of EGCG and incubated with ox-LDL. The wells were incubated at $37^{\circ} \mathrm{C}$ for $50 \mathrm{~min}$ in a $5 \% \mathrm{CO}_{2}$ incubator and washed 3 times with PBS to remove the non-adherent cells.

Morphological and immunohistochemistry analysis. The root of the aorta was obtained from the $\mathrm{ApoE}^{-/-}$mice and fixed in $4 \%$ paraformaldehyde overnight. Tissue specimens were then cut at $5 \mu \mathrm{m}$ thickness for subsequent hematoxylin and eosin (H\&E) staining or immunohistochemical analysis. The method for $\mathrm{H} \& \mathrm{E}$ staining of the aortic tissues was conducted as previously described (30). Immunohistochemical analysis was performed according to the manufacturer's instructions. The staining results were observed and captured using an AE31 light microscope (Motic, Xiamen, China).

Statistical analysis. Each experiment was repeated at least 3 times. Data are presented as the means \pm SE and analyzed using SPSS 18.0 software (SPSS, Inc., Chicago, IL, USA). Statistical comparisons between the groups were analyzed using a Student's t-test and a two-tailed value of $\mathrm{P}<0.05$ was considered to indicate a statistically significant difference.

\section{Results}

ox-LDL induces the apoptosis of endothelial cells. It has been previously demonstrated that ox-LDL induces endothelial cell apoptosis (31). As shown in Fig. 1A, MTT assay revealed that the incubation of HUVECs with ox-LDL (100 mg/l) enhanced endothelial cell apoptosis in a time-dependent manner. This result was also confirmed by flow cytometry (Fig. $1 \mathrm{~B}$ and $\mathrm{C}$ ). The HUVECs that were incubated with ox-LDL for $72 \mathrm{~h}$ were used in the subsequent experiments.

Jagged-1 affects the apoptosis of endothelial cells. To determine the potential effect of Jagged-1 on endothelial cell apoptosis, we transfected pCDNA3.1 vectors containing Jagged-1 (pCDNA3.1-Jagged-1) and transfected pRNAT-U6.1/ Neo vectors containing Jagged-1 shRNA (pRNAT-U6.1/ Neo-Jagged-1-sh) into the HUVECs in order to induce the overexpression or to silence Jagged-1, respectively. Western blot analysis revealed that the Jagged-1 levels were effectively downregulated following transfection of the cells with Jagged-1 shRNA, and significantly enhanced following transfection with pCDNA3.1-Jagged-1 (Fig. 2A). As shown in Fig. 2B and C, the silencing of Jagged-1 significantly enhanced the apoptosis of the HUVECs compared with the control group, and this effect was reversed by the overexpression of Jagged-1.

EGCG protects against ox-LDL-induced endothelial dysfunction. It has been previously demonstrated that the activation of NADPH oxidase is associated with ox-LDL-induced endothelial dysfunction $(32,33)$. As active NADPH oxidase is assembled on the membrane, the effects of EGCG on the membrane translocation of $\mathrm{p} 22^{\text {phox }}, \mathrm{p} 47^{\text {phox }}$ and $\mathrm{p} 67^{\text {phox }}$ were examined by RT-qPCR. As shown in Fig. 3, the levels of membrane-bound $\mathrm{p} 22^{\text {phox }}$ and $\mathrm{p} 47^{\text {phox }}$ were markedly decreased in the cells treated with ox-LDL for $72 \mathrm{~h}$ compared with the untreated cells (Fig 3). Of note, this decreasing effect on $\mathrm{p} 47^{\text {phox }}$ was enhanced by treatment with EGCG in a dose-dependent manner. In addition, treatment with EGCG enhanced p22 ${ }^{\text {phox }}$ expression, with a significant increase in expression being observed following treatment with $50 \mu \mathrm{M}$ EGCG $(\mathrm{P}<0.01)$. As regards $\mathrm{p} 67^{\text {phox }}$, the expression levels were slightly increased by ox-LDL and then decreased following treatment with $12.5 \mu \mathrm{M}$ EGCG. However, treatment with 50 and $200 \mu \mathrm{M}$ EGCG increased the levels of p6 $67^{\text {phox }}$ even further than ox-LDL did. The most significant effect on p $^{\text {phox }}$ expression was observed following treatment with $200 \mu \mathrm{M}$ EGCG (Fig. 3A-C). Moreover, ox-LDL decreased the expression of Jagged-1, and this effect was attenuated by treatment with $50 \mu \mathrm{M}$ EGCG (Fig. 3D). Western blot analysis revealed that treatment with $12.5 \mu \mathrm{M}$ EGCG further decreased Jagged-1 protein expression. However, treatment with $50 \mu \mathrm{M}$ EGCG attenuated this effect (Fig. 4).

Notch signaling has been proven to be critical for arterial specification, sprouting angiogenesis and vessel maturation (24-27). Thus, in this study, we examined the effects of Notch signaling on the EGCG-mediated protection against 

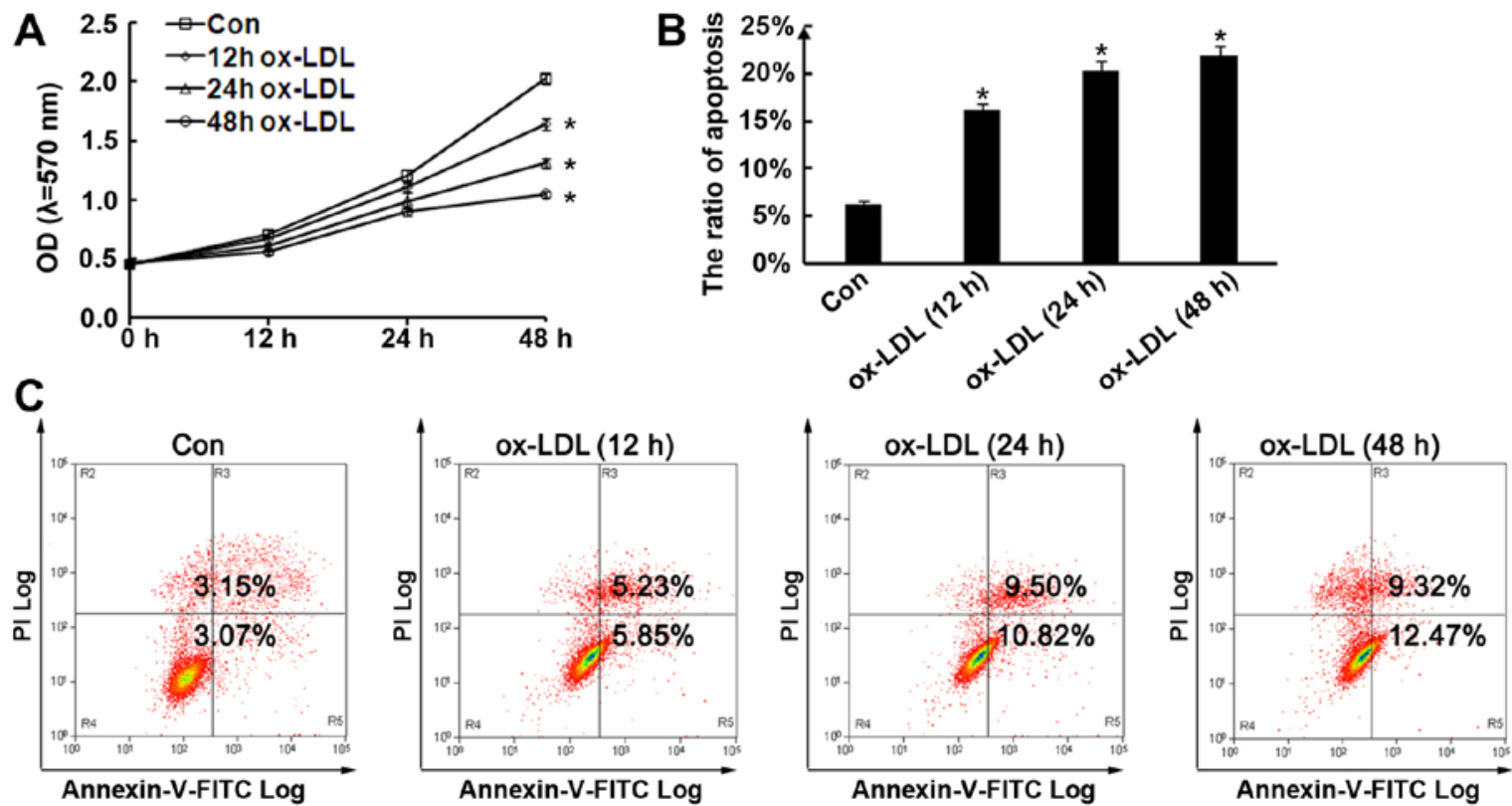

Figure 1. Oxidized low-density lipoprotein (ox-LDL) induces the apoptosis of endothelial cells. (A) Cell survival curve by MTT assay. (B and C) Cell apoptosis was examined by flow cytometry. Error bars represent the means $\pm \mathrm{SE} ;{ }^{*} \mathrm{P}<0.01$ vs. control (no treatment).

A

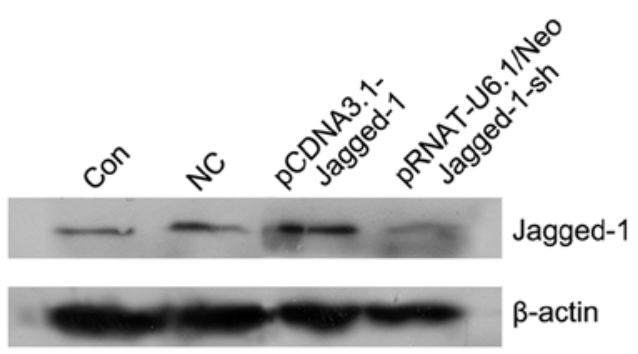

C

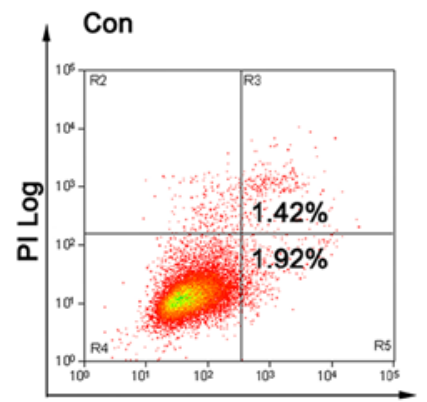

Annexin-V-FITC Log

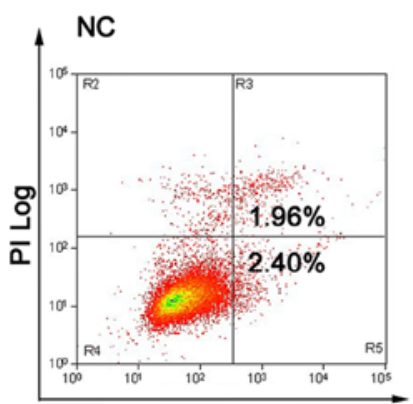

Annexin-V-FITC Log

B

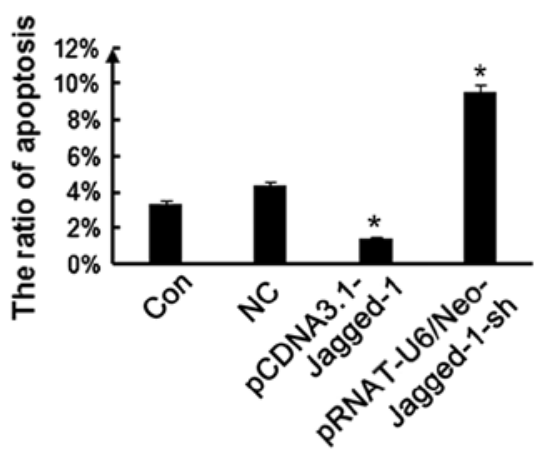

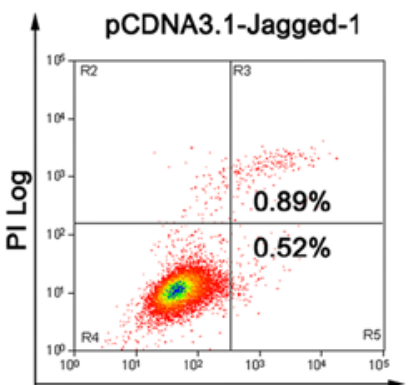

Annexin-V-FITC Log

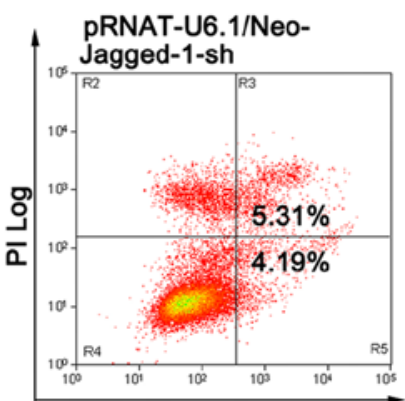

Annexin-V-FITC Log

Figure 2. Jagged-1 affects apoptosis of the endothelial cells. (A) Western blot analysis of the expression of Jagged-1. (B and C) Cell apoptosis was examined by flow cytometry. Error bars represent the means $\pm \mathrm{SE} ;{ }^{*} \mathrm{P}<0.01$ vs. control (no treatment).

ox-LDL-induced endothelial cell dysfunction. As shown in Fig. 4, the expression level of HES1 was significantly decreased following the exposure of the cells to ox-LDL. However, EGCG had no effect on HES1 expression in the ox-LDL + EGCG (12.5, 50 and $200 \mu \mathrm{M}$ ) groups compared with the ox-LDL group. The expression level of HES5 was increased following exposure of the cells to ox-LDL, and this effect was attenuated by treatment with $50 \mu \mathrm{M}$ EGCG. EGCG $(12.5$ and $200 \mu \mathrm{M})$ did not affect HES5 expression in the ox-LDL + EGCG (12.5 and $200 \mu \mathrm{M})$ groups compared with the ox-LDL group. Exposure of the cells to ox-LDL did not affect Math1 expression; however, treatment with EGCG decreased Math1 expression in a dose-dependent manner (Fig. 4).

It has been previously demonstrated that ox-LDL reduces the expression of eNOS, thereby altering endothelial biology (34). In the present study, we examined the effects of EGCG on the protein expression levels of eNOS and iNOS in endothelial cells exposed to ox-LDL. Our results revealed that ox-LDL 

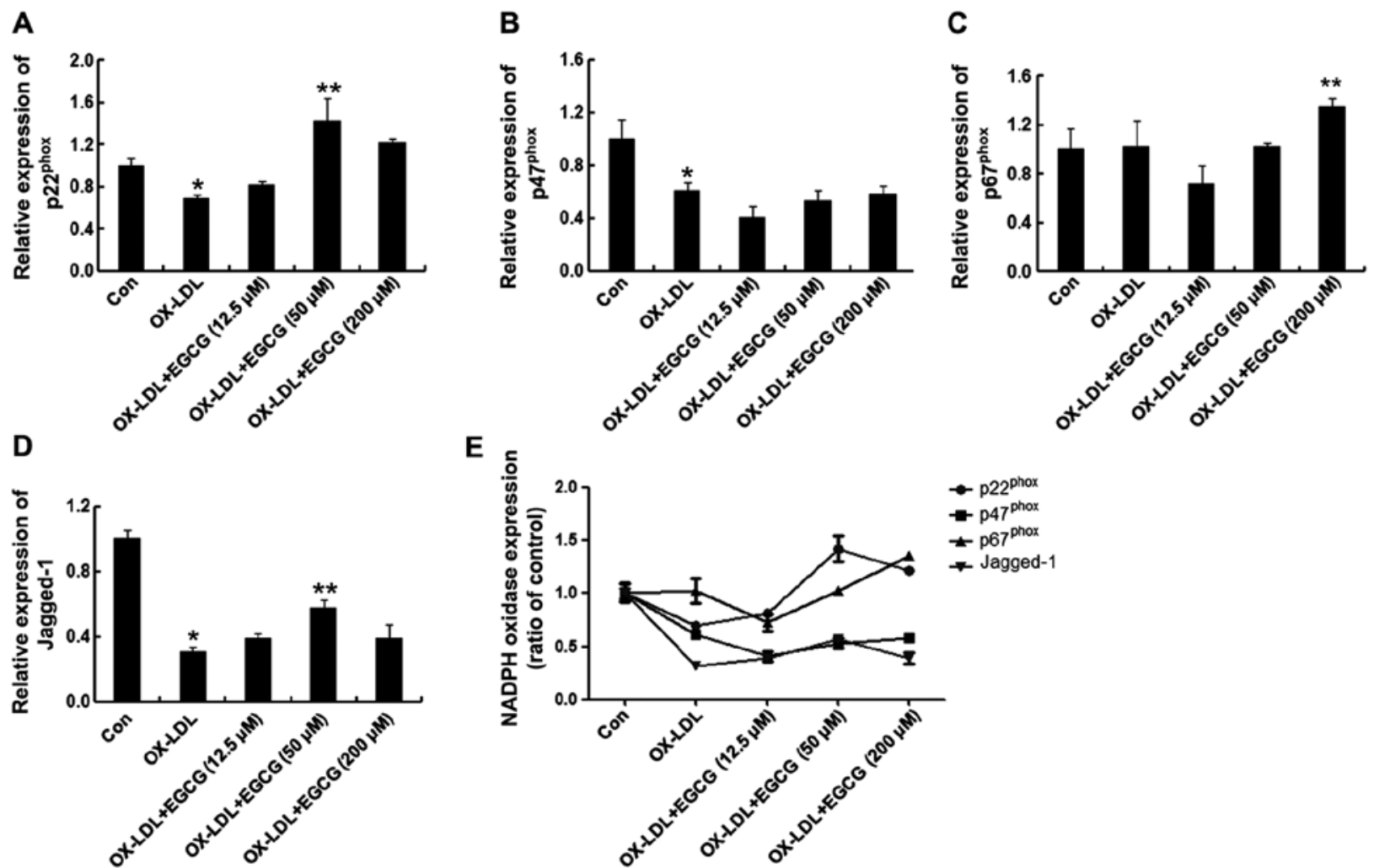

Figure 3. Effects of epigallocatechin-3-gallate (EGCG) on oxidized low-density lipoprotein (ox-LDL)-induced p22 $2^{\text {phox }}$, p47 $7^{\text {phox }}$ and p67 $7^{\text {phox }}$ membrane translocation Human umbilical vein endothelial cells (HUVECs) were treated with the indicated concentrations of EGCG (12.5-200 $\mu \mathrm{M}$ ) for $24 \mathrm{~h}$ followed by exposure to $100 \mathrm{mg} / \mathrm{l}$ ox-LDL for $72 \mathrm{~h}$. RT-qPCR was used to measure the mRNA expression levels of (A) NADPH p22 $2^{\text {phox }}$, (B) p47 $7^{\text {phox }}$ and (C) p67 ${ }^{\text {phox }}$. (D) RT-qPCR of the expression of Jagged-1. (E) Summary of the data indicating that EGCG prevents the ox-LDL-induced NADPH oxidase translocation to the plasma membrane. Error bars represent the means $\pm \mathrm{SE}$; ${ }^{*} \mathrm{P}<0.01$ vs. control (no treatment) and ${ }^{* *} \mathrm{P}<0.01$ vs. ox-LDL group.
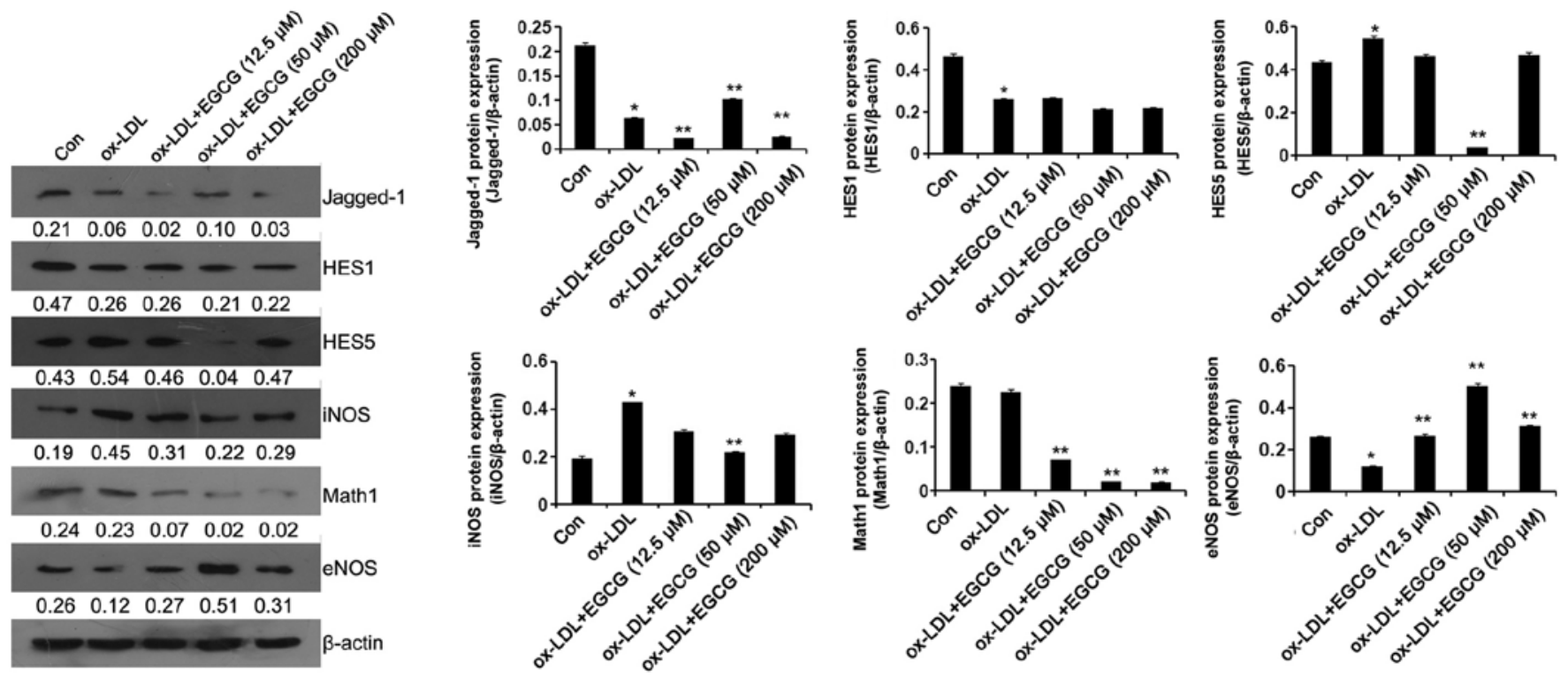

Figure 4. Western blot analysis revealed the expression of Jagged-1, HES1, HES5, iNOS, Math1, eNOS in human umbilical vein endothelial cells (HUVECs). HUVECs were treated with the indicated concentrations of epigallocatechin-3-gallate (EGCG) $(12.5-200 \mu \mathrm{M})$ for $24 \mathrm{~h}$ followed by exposure to $100 \mathrm{mg} / \mathrm{lox}-\mathrm{LDL}$ for $72 \mathrm{~h}$. Error bars represent the means $\pm \mathrm{SE}$; ${ }^{*} \mathrm{P}<0.01$ vs. control (no treatment) and ${ }^{* *} \mathrm{P}<0.01$ vs. ox-LDL group.

significantly reduced eNOS protein expression and increased iNOS protein expression compared with the control group. This effect was attenuated significantly in the cells treated with $50 \mu \mathrm{M}$ EGCG. Treatment with $50 \mu \mathrm{M}$ EGCG signficantly increased eNOS protein expression compared with the cells in the ox-LDL group. Treatment with EGCG at $12.5 \mu \mathrm{M}$ promoted ox-LDL-induced endothelial dysfunction, whereas EGCG at $50 \mu \mathrm{M}$ protected the cells against ox-LDL-induced endothelial 

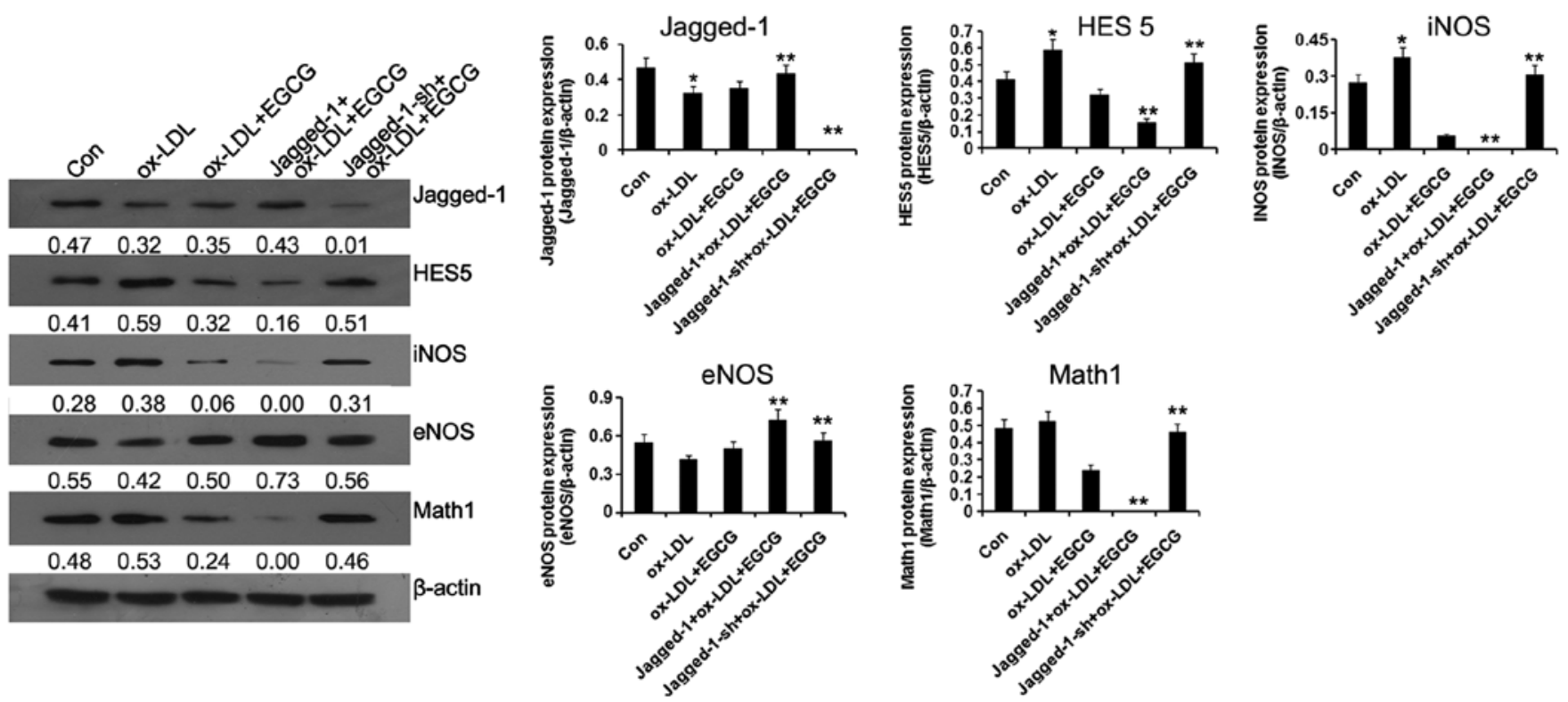

Figure 5. Western blot analysis of the expression of Jagged-1, HES5, iNOS, Math1 and eNOS in endothelial progenitor cells (EPCs). EPCs were treated with epigallocatechin-3-gallate (EGCG) $(50 \mu \mathrm{M})$ for $24 \mathrm{~h}$ followed by exposure to $100 \mathrm{mg} / 1$ oxidized low-density lipoprotein (ox-LDL) for $72 \mathrm{~h}$. Error bars represent the means $\pm \mathrm{SE} ;{ }^{*} \mathrm{P}<0.01$ vs. the control (no treatment) and ${ }^{* *} \mathrm{P}<0.01$ vs. the ox-LDL group.

cell dysfunction through the Notch signaling pathway. Thus, the concentration of $50 \mu \mathrm{M}$ EGCG was used in the subsequent experiments.

Jagged-1 is the key effector protein through which EGCG exerts its protective effects against ox-LDL-induced endothelial cell dysfunction. The overexpression and silencing of Jagged-1 was induced in order to determine the role of Jagged-1 in the EGCG-mediated protection against ox-LDL-induced endothelial dysfunction. EPCs were obtained from $\mathrm{ApoE}^{-/-}$mice and treated with EGCG $(50 \mu \mathrm{M})$ for $24 \mathrm{~h}$ followed by exposure to $100 \mathrm{mg} / \mathrm{l}$ ox-LDL for $72 \mathrm{~h}$. As shown in Fig. 5, the overexpression of Jagged-1 markedly decreased the expression levels of HES5, iNOS and Math1, and increased the expression levels of eNOS in the Jagged-1 + ox-LDL + EGCG group compared with the ox-LDL + EGCG group. By contrast, the silencing of Jagged-1 markedly increased the expression levels of HES5, iNOS and Math1, and decreased the expression levels of eNOS in the Jagged-1-sh + ox-LDL + EGCG group compared with the ox-LDL + EGCG group.

Furthermore, we examined the effects of Jagged-1 on apoptosis, as well as on the adhesiveness of EPCs. As shown in Fig. 6A and B, MTT assay and flow cytometric analysis revealed that EGCG suppressed ox-LDL-induced cell apoptosis. This effect was enhanced by the overexpression of Jagged-1, but inhibited by the silencing of Jagged-1. In addition, EGCG attenuated the decrease in cell adhesion induced by ox-LDL, and this effect was inhibited by the silencing of Jagged-1 (Fig. 6C). Thus, our results indicate that Jagged-1 is the key effector protein through which EGCG exerts its protective effects against ox-LDL-induced endothelial dysfunction.

Histomorphometric analysis of the aortic sinus. To directly determine the protective effects of EGCG against the development of atherosclerosis, the characteristics of arterial lesions were examined by pathological section H\&E staining using light microscopy (Fig. 7). In the control group, the vessel walls were round with even thicknesses. The endothelial cell core was stained and evenly arranged. In the HFD group, the vessel walls were uneven, and significant intimal hyperplasia was present. The inner elastic plates were broken. Treatment with EGCG resulted in more even blood vessels and smoother intima. Histomorphological analysis revealed that EGCG attenuated the HFD-induced accumulation of atherosclerotic plaque. Furthermore, we found that the expression of Jagged-1 and HES5 was upregulated in the HFD group (shown by increased dark brown staining), and this effect was attenuated in the HFD + EGCG group. These results indicated that impairment of the vascular endothelium induced the activation of the Jagged-1/Notch pathway, which was associated with significant intimal hyperplasia.

\section{Discussion}

Atherosclerosis is a multifactor cardiovascular disease, and ox-LDL is a particularly important factor in the pathogenesis of atherosclerosis and it contributes to endothelial damage. In the present study, we demonstrate that EGCG at a concentration of $50 \mu \mathrm{M}$ protected against ox-LDL-induced endothelial cell apoptosis and inhibited the development and progression of atherosclerosis. We also investigated the possible mechanisms responsible for these effects.

EGCG is found in green tea, and it has potent antioxidant, anti-mitotic and anti-angiogenic properties (35). The antioxidant activity of EGCG has been widely demonstrated in vitro and in vivo $(15,36)$. The antioxidant activity of EGCG is repsonsibel for its protective effects against atherosclerosis (37). Consistent with these results, the present study demonstrated that treatment with $50 \mu \mathrm{M}$ EGCG evidently reduced ox-LDLinduced cell apoptosis and the ox-LDL-induced decrease in the 
A 1.20 - 1 Jagged-1-Sh+ox-LDL+EGCG

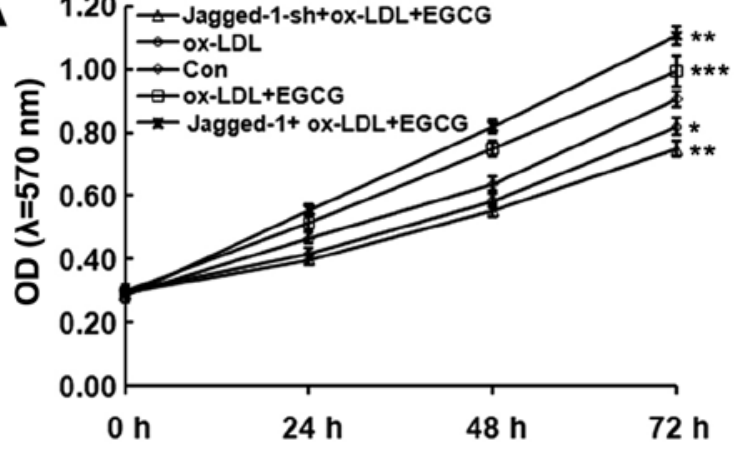

C

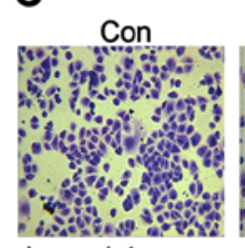

Jagged-1+

ox-LDL+EGCG

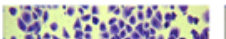

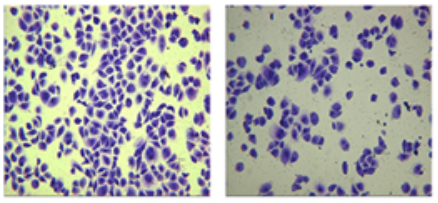

B
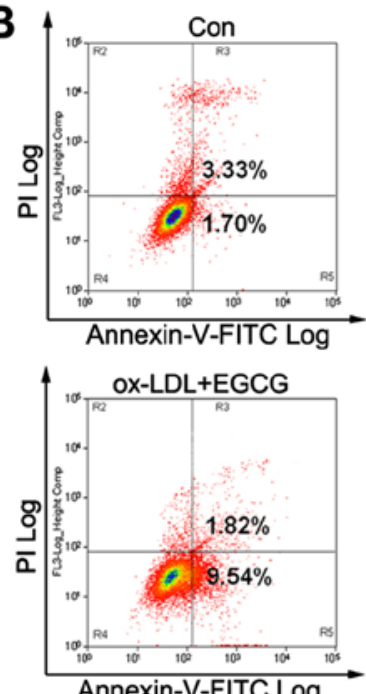

Annexin-V-FITC Log

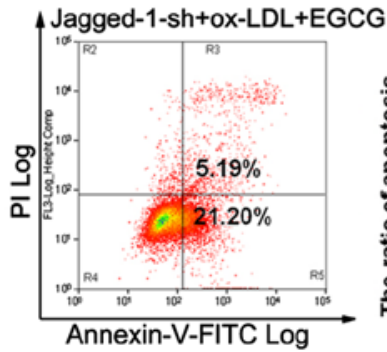

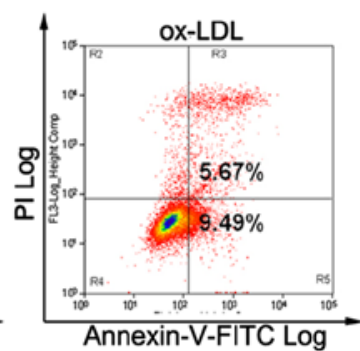
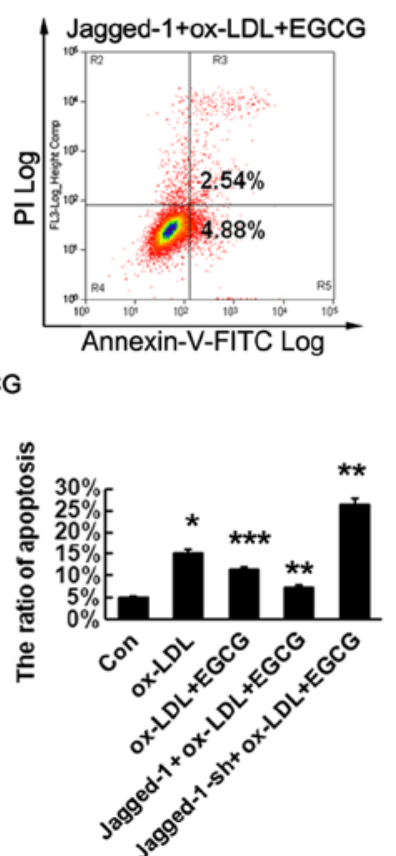

Figure 6. Effects of Jagged-1 and epigallocatechin-3-gallate (EGCG) on oxidized low-density lipoprotein (ox-LDL)-induced apoptosis and the adhesion of endothelial progenitor cells (EPCs). EPCs were pre-treated with EGCG (50 $\mu \mathrm{M}$ ) for $24 \mathrm{~h}$ followed by exposure to $100 \mathrm{mg} / 1$ ox-LDL for $72 \mathrm{~h}$. (A) Cell survival curve by MTT assay. (B) Cell apoptosis was examined by flow cytometry. (C) Cell adhesion was examined. Error bars represent the means \pm SE; ${ }^{*} \mathrm{P}<0.01$ vs. control (no treatment), ${ }^{* *} \mathrm{P}<0.01$ vs. ox-LDL + EGCG group and ${ }^{* * *} \mathrm{P}<0.01$ vs. ox-LDL group.

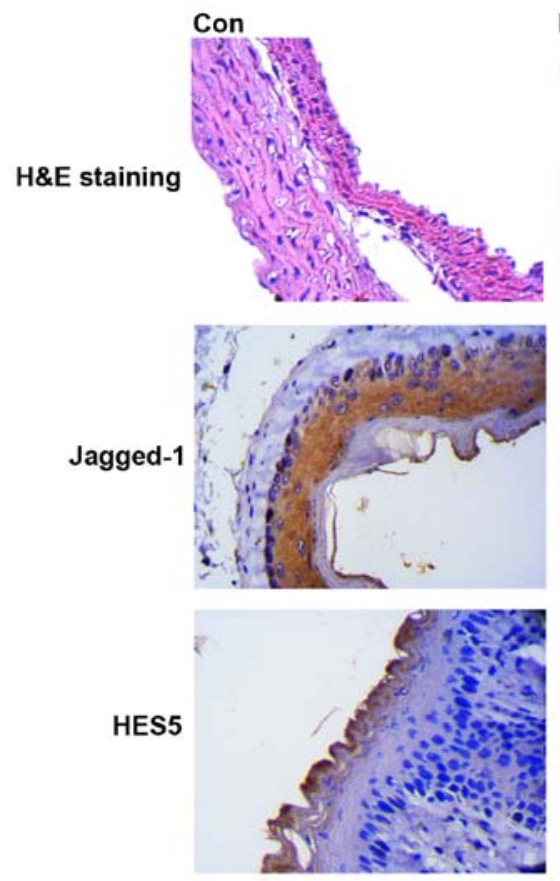

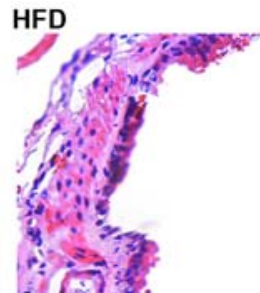
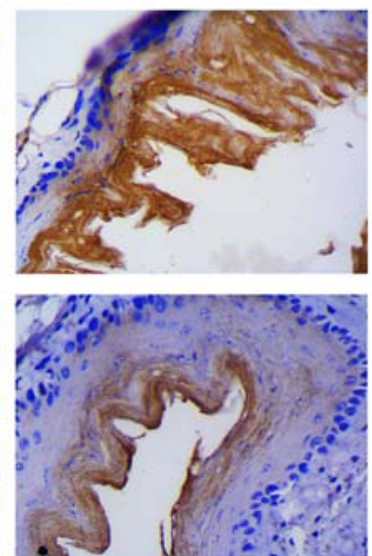

HFD+EGCG
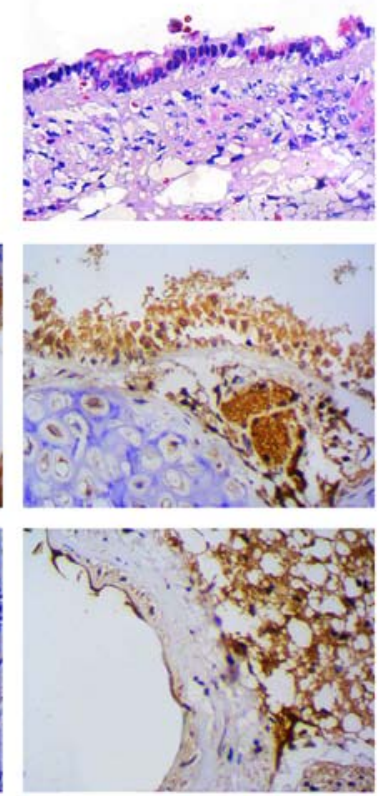

Figure 7. Formation of atherosclerotic plaque in the aortic sinuses of ApoE knockout (ApoE-KO) mice. Pathological sections of arterial lesions were examined by H\&E staining, and the protein expression of Jagged-1 and HES5 was examined by immunohistochemistry. Three 10-week-old ApoE-KO mice were used as normal controls. In the control group, the vessel walls were thin and smooth with even thicknesses. Four mice were fed a high-fat diet (HFD) in the HFD group. In the HFD + EGCG group, 4 mice were fed a HFD and then treated with $0.8 \mathrm{~g} / 1$ ECGC. Magnification, $\mathrm{x} 400$. 
adhesion of endothelial cells. However, treatment with a lower concentration of EGCG $(12.5 \mu \mathrm{M})$ for $24 \mathrm{~h}$ may not be sufficient to exert antioxidant effects, and the higher concentration of EGCG $(200 \mu \mathrm{M})$ may promote the apoptosis of damaged endothelial cells. Taken together, these findings suggest that treatment with EGCG at the concentration of $50 \mu \mathrm{M}$ exerts the optimal antioxidant effects.

iNOS is known to play a role in producing NO during inflammation, and thus it contributes to the initiation and development of inflammatory cardiovascular diseases, such as atherosclerosis. As previously demonstrated, mice lacking the endothelial isoform are generally hypertensive and have a more severe outcome to diet-induced atherosclerosis. Mice lacking the neuronal isoform have increased diet-induced atherosclerosis. Mice lacking the inducible isoform show reduced hypotension to septic shock (38). ox-LDL has been shown to reduce the expression of eNOS, thereby altering endothelial biology (34). It has also been demonstrated that EGCG prevents the ox-LDL-decrease in eNOS protein expression HUVECs (39). In this study, we found that treatment with $50 \mu \mathrm{M}$ EGCG prevented the ox-LDL-induced decrease in eNOS expression and the ox-LDL-induced increase in iNOS protein expression in HUVECs. Accumulating evidence has indicated that the ox-LDL-mediated biological processes may be related to the increased activity of NADPH oxidase (6-8). It has been demonstrated that ox-LDL-induced endothelial dysfunction is caused by an increase in NADPH oxidase-generated superoxide concentrations and a decrease in antioxidant enzyme activity (40). This indicates that ox-LDL mediates endothelial cell damage by suppressing the activity of NADPH oxidase. In this study, we demonstrated that EGCG attenuated the ox-LDL-induced decrease in NADPH oxidase activity by significantly increasing the expression of $\mathrm{p} 22^{\text {phox }}$ in endothelial cells, indicating that EGCG protects against ox-LDL-mediated endothelial cell (HUVEC) damage by increasing the expression of NADPH oxidase $\mathrm{p} 22^{\text {phox }}$ in endothelial cells.

Notch signaling within endothelial cells plays a critical role during developmental angiogenesis, providing instructive cues to neighboring endothelial cells through Notch ligandreceptor interactions typical of the canonical Notch signaling pathway. The Notch pathway is a highly conserved signaling system that is essential for vascular development, homeostasis and angiogenesis. In growing blood vessels, the sprouting of endothelial tip cells is inhibited by Notch signaling and the precise equilibrium between two Notch ligands with distinct spatial expression patterns and opposing functional roles regulates angiogenesis (41). In the present study, ox-LDL suppressed Notch ligand Jagged-1 expression and induced Notch target gene HES5 expression. These effects were reversed by treatment with EGCG. Moreover, Jagged-1 suppressed apoptosis and promoted adhesion of EPCs. In conclusion, Jagged-1 is the key effector protein in the protective effects of EGCG against ox-LDL-induced endothelial dysfunction through the Notch pathway.

To directly determine the effects of EGCG on the development of atherosclerosis and the mechanisms involved, the characteristics of arterial lesions were examined by pathological section H\&E staining using light microscopy. The results demonstrated that EGCG evidently inhibited HFD-induced atherosclerosis in ApoE-KO mice, which was associated with the expression of Jagged-1 and HES5, indicating that EGCG protects ApoE-KO mice from atherosclerosis through the Jagged-1/Notch pathway. These findings are consistent with those of a previous study indicating that EGCG prevented the development of atherosclerosis in ApoE-KO mice by reducing LDL-induced susceptibility to oxidation (42).

In conclusion, the findings of our study demonstrate that EGCG protects against ox-LDL-induced endothelial cell damage through the Jagged-1-mediated Notch pathway, both in vitro and in vivo. The manipulation of the components of this mechanism may prove to be a potential therapeutic strategy for preventing atherosclerosis.

\section{References}

1. Stocker R and Keaney JF Jr: Role of oxidative modifications in atherosclerosis. Physiol Rev 84: 1381-1478, 2004.

2. Galkina E and Ley K: Immune and inflammatory mechanisms of atherosclerosis (*). Annu Rev Immunol 27: 165-197, 2009.

3. Parthasarathy S, Raghavamenon A, Garelnabi MO and Santanam N: Oxidized low-density lipoprotein. Methods Mol Biol 610: 403-417, 2010.

4. Chisolm GM and Steinberg D: The oxidative modification hypothesis of atherogenesis: an overview. Free Radic Biol Med 28: 1815-1826, 2000.

5. Miller NJ and Paganga G: Antioxidant activity of low-density lipoprotein. Methods Mol Biol 108: 325-335, 1998.

6. Zhao W, Ma G and Chen X: Lipopolysaccharide induced LOX-1 expression via TLR4/MyD88/ROS activated p38MAPK-NF-кB pathway. Vascul Pharmacol 63: 162-172, 2014.

7. Carnevale R, Bartimoccia S, Nocella C, Di Santo S, Loffredo L, Illuminati G, Lombardi E, Boz V, Del Ben M, De Marco L, et al: LDL oxidation by platelets propagates platelet activation via an oxidative stress-mediated mechanism. Atherosclerosis 237: 108-116, 2014.

8. Cominacini L, Rigoni A, Pasini AF, Garbin U, Davoli A, Campagnola M, Pastorino AM, Lo Cascio V and Sawamura T: The binding of oxidized low density lipoprotein (ox-LDL) to ox-LDL receptor-1 reduces the intracellular concentration of nitric oxide in endothelial cells through an increased production of superoxide. J Biol Chem 276: 13750-13755, 2001.

9. Sakamoto N, Ishibashi T, Sugimoto K, Sawamura T, Sakamoto T, Inoue N, Saitoh S, Kamioka M, Uekita $\mathrm{H}$, Ohkawara $\mathrm{H}$, et al: Role of LOX-1 in monocyte adhesion-triggered redox, Akt/ eNOS and $\mathrm{Ca}^{2+}$ signaling pathways in endothelial cells. J Cell Physiol 220: 706-715, 2009.

10. Wolfram S: Effects of green tea and EGCG on cardiovascular and metabolic health. J Am Coll Nutr 26: 373S-388S, 2007.

11. Feng Q, Kumagai T, Torii Y, Nakamura Y, Osawa T and Uchida K: Anticarcinogenic antioxidants as inhibitors against intracellular oxidative stress. Free Radic Res 35: 779-788, 2001.

12. Tipoe GL, Leung TM, Hung MW and Fung ML: Green tea polyphenols as an anti-oxidant and anti-inflammatory agent for cardiovascular protection. Cardiovasc Hematol Disord Drug Targets 7: 135-144, 2007.

13. Mukhtar H and Ahmad N: Tea polyphenols: prevention of cancer and optimizing health. Am J Clin Nutr 71: 1698S-1704S-1702S; discussion 1703S-1694S, 2000.

14. Cao Y and Cao R: Angiogenesis inhibited by drinking tea. Nature 398: 381, 1999.

15. Cai Y, Kurita-Ochiai T, Hashizume T and Yamamoto M: Green tea epigallocatechin-3-gallate attenuates Porphyromonas gingivalis-induced atherosclerosis. Pathog Dis 67: 76-83, 2013.

16. Choi YJ, Kang JS, Park JH, Lee YJ, Choi JS and Kang YH: Polyphenolic flavonoids differ in their antiapoptotic efficacy in hydrogen peroxide-treated human vascular endothelial cells. J Nutr 133: 985-991, 2003.

17. Choi JS, Choi YJ, Shin SY, Li J, Kang SW, Bae JY, Kim DS, Ji GE, Kang JS and Kang YH: Dietary flavonoids differentially reduce oxidized LDL-induced apoptosis in human endothelial cells: Role of MAPK- and JAK/STAT-signaling. J Nutr 138: 983-990, 2008.

18. Ahn HY and Kim $\mathrm{CH}$ : Epigallocatechin-3-gallate regulates inducible nitric oxide synthase expression in human umbilical vein endothelial cells. Lab Anim Res 27: 85-90, 2011. 
19. Ahn HY, Kim $\mathrm{CH}$ and $\mathrm{Ha}$ TS: Epigallocatechin-3-gallate regulates NADPH oxidase expression in human umbilical vein endothelial cells. Korean J Physiol Pharmacol 14: 325-329, 2010.

20. Giniger E: Notch signaling and neural connectivity. Curr Opin Genet Dev 22: 339-346, 2012.

21. Artavanis-Tsakonas S, Delidakis $\mathrm{C}$ and Fehon RG: The Notch locus and the cell biology of neuroblast segregation. Annu Rev Cell Biol 7: 427-452, 1991.

22. Koch U, Lehal R and Radtke F: Stem cells living with a Notch. Development 140: 689-704, 2013.

23. Liu J, Sato C, Cerletti M and Wagers A: Notch signaling in the regulation of stem cell self-renewal and differentiation. Curr Top Dev Biol 92: 367-409, 2010.

24. Tu J, Li Y and Hu Z: Notch1 and 4 signaling responds to an increasing vascular wall shear stress in a rat model of arteriovenous malformations. Biomed Res Int 2014: 368082, 2014.

25. Guichet PO, Guelfi S, Teigell M, Hoppe L, Bakalara N, Bauchet L, Duffau H, Lamszus K, Rothhut B and Hugnot JP: Notch1 stimulation induces a vascularization switch with pericyte-like cell differentiation of glioblastoma stem cells. Stem Cells 33: 21-34, 2015.

26. Lee SH, Lee S, Yang H, Song S, Kim K, Saunders TL, Yoon JK, Koh GY and Kim I: Notch pathway targets proangiogenic regulator Sox17 to restrict angiogenesis. Circ Res 115: 215-226, 2014.

27. Caolo V, Molin DG and Post MJ: Notch regulation of hematopoiesis, endothelial precursor cells, and blood vessel formation: orchestrating the vasculature. Stem Cells Int 2012: 805602, 2012.

28. Kalka C, Masuda H, Takahashi T, Kalka-Moll WM, Silver M, Kearney M, Li T, Isner JM and Asahara T: Transplantation of ex vivo expanded endothelial progenitor cells for therapeutic neovascularization. Proc Natl Acad Sci USA 97: 3422-3427, 2000.

29 Liu B, Che W, Xue J, Zheng C, Tang K, Zhang J, Wen J and Xu Y: SIRT4 prevents hypoxia-induced apoptosis in H9c2 cardiomyoblast cells. Cell Physiol Biochem 32: 655-662, 2013.

30. Li H, Dai M and Jia W: Paeonol attenuates high-fat-diet-induced atherosclerosis in rabbits by anti-inflammatory activity. Planta Med 75: 7-11, 2009.

31. Liu S, Shen H, Xu M, Liu O, Zhao L, Liu S, Guo Z and Du J: FRP inhibits ox-LDL-induced endothelial cell apoptosis through an Akt-NF-(kappa)B-Bcl-2 pathway and inhibits endothelial cell apoptosis in an apoE-knockout mouse model. Am J Physiol Endocrinol Metab 299: E351-E363, 2010.
32. Bai YP, Hu CP, Yuan Q, Peng J, Shi RZ, Yang TL, Cao ZH, Li YJ, Cheng G and Zhang GG: Role of VPO1, a newly identified heme-containing peroxidase, in ox-LDL induced endothelial cell apoptosis. Free Radic Biol Med 51: 1492-1500, 2011.

33. Jia SJ, Jiang DJ, Hu CP, Zhang XH, Deng HW and Li YJ: Lysophosphatidylcholine-induced elevation of asymmetric dimethylarginine level by the NADPH oxidase pathway in endothelial cells. Vascul Pharmacol 44: 143-148, 2006.

34. Xu H, Duan J, Wang W, Dai S, Wu Y, Sun R and Ren J: Reactive oxygen species mediate oxidized low-density lipoprotein-induced endothelin-1 gene expression via extracellular signal-regulated kinase in vascular endothelial cells. J Hypertens 26: 956-963, 2008.

35. Nagle DG, Ferreira D and Zhou YD: Epigallocatechin-3gallate (EGCG): Chemical and biomedical perspectives. Phytochemistry 67: 1849-1855, 2006.

36. Persson IA, Josefsson M, Persson K and Andersson RG: Tea flavanols inhibit angiotensin-converting enzyme activity and increase nitric oxide production in human endothelial cells. J Pharm Pharmacol 58: 1139-1144, 2006.

37. Hishikawa K, Nakaki T and Fujita T: Oral flavonoid supplementation attenuates atherosclerosis development in apolipoprotein E-deficient mice. Arterioscler Thromb Vasc Biol 25: 442-446, 2005.

38. Liu VW and Huang PL: Cardiovascular roles of nitric oxide: a review of insights from nitric oxide synthase gene disrupted mice. Cardiovasc Res 77: 19-29, 2008.

39. Huang JJ, Shi YQ, Li RL, Hu A, Lu ZY, Weng L, Wang SQ, Han YP, Zhang L, Li B, et al: Angiogenesis effect of therapeutic ultrasound on HUVECs through activation of the PI3K-AkteNOS signal pathway. Am J Transl Res 7: 1106-1115, 2015.

40. Rueckschloss U, Duerrschmidt N and Morawietz H: NADPH oxidase in endothelial cells: impact on atherosclerosis. Antioxid Redox Signal 5: 171-180, 2003

41. Chen T, Margariti A, Kelaini S, Cochrane A, Guha ST, Hu Y, Stitt AW, Zhang L and Xu Q: MicroRNA-199b modulates vascular cell fate during iPS cell differentiation by targeting the notch ligand jagged1 and enhancing VEGF signaling. Stem Cells 33: 1405-1418, 2014.

42. Miura Y, Chiba T, Tomita I, Koizumi H, Miura S, Umegaki $\mathrm{K}$, Hara Y, Ikeda M and Tomita T: Tea catechins prevent the development of atherosclerosis in apoprotein E-deficient mice. J Nutr 131: 27-32, 2001. 